\title{
MALAYSIAN \\ ORTHOPAEDIC \\ JOURNAL
}

Vol 11 No 2, July 2017

Official Journal of Malaysian Orthopaedic Association, ASEAN Orthopaedic Association

CHIEF EDITOR

Saw Aik

EDITORIAL BOARD

Abdul Hamid Abdul Kadir

Abdul Razak Sulaiman

Aree Tanavalee

Awang Bulgiba

Azlina Amir Abbas

Edward HM Wang

Ifran Saleh

Kitti Jirarattanaphochai

Kwan Mun Keong

Mohd Imran Yusof

Mohammad Anwar Hau Abdullah

Myint Thaung

Ng Kwan Hoong

Sharaf Ibrahim

Tunku Sara Ahmad

ASEAN REGIONAL EDITORIAL BOARD

Nathaniel Orillaza (Philippine)

Howe Tet Sen (Singapore)

James Hui (Singapore)

Luthfi Gatam (Indonesia)

Nguyen Le Bao Tien (Vietnam)

Vo Van Thanh (Vietnam)

Saranatra Waikakul (Thailand)

Ketan Pande (Brunei)
INTERNATIONAL ADVISORY BOARD

Aziz Nather (Singapore)

Benjamin Joseph (India)

Christopher Mow (USA)

Kaye E Wilkins (USA)

Ken N Kuo (USA)

Lee Eng Hin (Singapore)

Wilfred Peh (Singapore)

EDITORIAL SECRETARY

Nurul Jannah Mohd Azmi

EDITORIAL ASSISTANT

Nurul Atiqah Abdul Rahim

ADMINISTRATION SECRETARY

Uma Sundaram

MOJ WEBMASTER

Teng Kim Teck

PUBLISHER

Malaysian Orthopaedic

Association

Secretariat

Malaysian Orthopaedic Journal

Unit 2.6, Level 2, Technology Park Malaysia (TPM), Enterprise 3B, Lebuhraya Puchong-Sg. Besi,

57000 Bukit Jalil, Kuala Lumpur

Tel: +603 40251300 Fax: +603 40251400

Email: morthoj@gmail.com Website: www.morthoj.org/

KDN No : PP 15451/06/2013(032812) 


\section{ORIGINAL ARTICLES}

Knowledge on Bone Banking among Participants in an Orthopaedic Conference: A Preliminary Survey 1 Mohd S, Yusof N, Ramalingam S, Ng WM, Mansor A

Psychometric Properties of the Malay Language Version of Knee Injury and Osteoarthritis Outcome Score (KOOS) Questionnaire among Knee Osteoarthritis Patients: A Confirmatory Factor Analysis

Zulkifli MM, Kadir AA, Elias A, Bea KC, Sadagatullah AN

Comparative Study of Proximal Tibia and Iliac Crest Bone Graft Donor Sites in Treatment of Orthopaedic Pathologies

Salawu ON, Babalola OM, Ahmed BA, Ibraheem GH, Kadir DM

Functional Outcome of Isolated Hoffa Fractures Treated with Cannulated Cancellous Screw

Singh $R$, Singh $R B$, Mahendra $M$

Endoprosthetic Reconstruction of distal Humerus following Resection of distal Humeral Giant Cell Tumours in Six Patients in Rural India

Balasubramanian $N$, Gnanasundaram R, Prakasam $S$

Coracoid Process Morphology using 3D-CT Imaging in a Malaysian Population

Nizlan NM, Imma II, Ezamin AR, Yusoff S, Shukur MH

Determining if Positive Predictive Value using Laboratory Risk Indicator for Necrotising Fasciitis is Applicable in Malaysian Patients with Necrotising Fasciitis

Syed A, Alvin T, Fazrina A, Abdul $R$

Displaced Supracondylar Humerus Fractures in Children - Are They All Identical?

Gera SK, Tan MCH, Lim YG, Lim KBL

A Comparison of Plain Radiography with Computer Tomography in Determining Coronal and Sagittal Alignments following Total Knee Arthroplasty

Solayar GN, Chinappa J, Harris IA, Chen DB, Macdessi SJ

Use of Titanium Elastic Nails in the Adult Diaphyseal Humerus Fractures

Upadhyay AS, Lil NA

\section{CASE REPORTS}

Chronic Traumatic Sagittal Band Injury with Extensor Tendon Dislocation: Report of a Case and New Surgical Technique

Or SY, Khaw YC, Hwang PX, Ong TK

Primary Osteosarcoma of the Distal Fibula treated with Distal Fibulectomy with a Five-Year Follow-up:

A Case Report

Saadon I, Amit B, Zolquarnain A, Muhamad F 
Brodie's Abscess of Posterior Ilium with Gluteal Syndrome, an Unusual Cause of Paediatric Low Back Pain: A Case Report

Behera $G$, Poduval M, Patro DK, Sahoo $S$

Life-threatening Chlorhexidine Anaphylaxis: A Case Report

Kow RY, Low CL, Ruben JK, Zaharul-Azri MZ, Ng MS

Fracture-dislocation at C6-C7 level with Quadriplegia after Traditional Massage in a Patient with Ankylosing Spondylitis: A Case Report

Abilash KAK, Mohd QMQ, Ahmad ZAH, Basir Towil

Antibiotic-laden Arthroplasty with a Novel Design of Cement Mould and Metallic

Endoskeleton for Treatment of Hip Infection, an Inexpensive Alternative: A Preliminary Report of Two Cases

William CCH, Simmrat S, Suhaeb AM

A Modified Technique of Fixation for Proximal Femoral Valgus Osteotomy in Abnormal Bone:

A Report of Two Cases

Logheswaren S, Sulaiman AR, Munajat I

A Good Short-term Outcome in Delayed Decompression of Cauda Equina Syndrome in

Klebsiella pneumoniae Spinal Epidural Abscess: A Case Report

Hanifah J, Joehaimey J, Yusof MI

\section{BOOK REVIEW}

Clinical Leadership in Nursing and Healthcare: Values into Action, 2nd Edition

Sharaf Ibrahim

INSTRUCTIONS FOR AUTHORS

FUTURE EVENTS

EXECUTIVE COMMITTEE OF MALAYSIAN ORTHOPAEDIC

ASSOCIATION 2017-2018 